\title{
SYMMETRICAL EPIPHYSEAL DESTRUCTION BY FROSTBITE
}

\author{
BY \\ L. FLORKIEWICZ and K. KOZLOWSKI* \\ From the I Pediatric Clinic of the Medical School in Poznan, Poland
}

(RECEIVED FOR PUBLICATION AUGUST 14, 1961)

There have been only single reports about the radiological changes in bones subsequent to frostbite in childhood and adolescence. We found only three cases on this subject in the literature. Löhr (1930) described a case in a 16-year-old boy; Bennett and Blount (1935) published the report of an 8-year-old girl, and Thelander (1950) of a 9-yearold boy. There are some thorough studies on this subject among adults, especially from the second World War (Appelrath, 1943) and the Korean War (Vinson and Schatzki, 1954).

Jäger (1943), from observations on soldiers, describes the following findings as specific for frostbite: smoothing of the tuberositas inguicuales, cartilage atrophy of the interphalangeal joints, small punched-out areas of decreased density in the juxta-articular joints, and small destructive changes in the cartilages of the joints and the surrounding bones, with secondary arthrosis deformans.

Appelrath (1943) stresses the susceptibility of the cartilage to frostbite. He often found definite evidence of damage to the cartilage of the interphalangeal joints without radiological signs in the phalanges. He claims that the earliest radiological findings were the narrowing or disappearance of the articular spaces which were first noted after about two months. According to him, this was due to the difference in the vascular structure of the bones and the cartilage. In more severe cases there were necrotic changes in the bones. Later, secondary arthritic deformities appeared. A diffuse osteoporosis was often apparent.

Vinson and Schatzki (1954) observed the bone changes occurring in a group of 100 enlisted men with frostbite. They classified the radiographic changes into four groups: (1) osteoporosis; (2) acromutilation (mutilation of terminal phalanges due to exposed bone); (3) late changes in the bones close to the joints of feet or hands, and (4) other bone changes.

\footnotetext{
* Radiologist of the I Pediatric Clinik, Poznan, Poland.
}

\section{Case Report}

J.W., a 5-year-old boy, was admitted to the I Pediatric Clinic in Poznan, Poland, in June 1958, because of deformities of the distal interphalangeal joints of 18 months' duration. The mother claimed that they were due to frostbite two and a half years before. The development of the child was otherwise normal. The parents, two brothers and a sister of the family were healthy.

At the time of admission the skin of the fingers and the nails was normal. A flexor deformity of the distal interphalangeal joints in the second, third and fourth left digits, and the second, third, fourth and fifth right digits, with some swelling and limitation of movements, was noted. No other abnormalities were found on physical examination. All the laboratory findings, including calcium, phosphorus and alkaline phosphatase were normal.

The radiological examination (Fig. 1) disclosed that the epiphyses of the second, third, fourth and fifth right distal phalanges and the second and fourth left distal phalanges were absent. There was a rudimentary epiphysis of the third left distal phalanx. The interphalangeal spaces between the middle and the distal phalanges of the third and fourth right fingers were absent, and those of the second and fifth right, and second, third and fourth left fingers were narrowed. The metaphyses of these phalanges, more marked on the right side, were irregular and sclerotic. The distal interphalangeal joints were angulated with the apex radially. All the other long bones, and the bones of the hands and feet of all the members of the family were normal.

\section{Discussion}

In our case the distal interphalangeal joints with the distal epiphyseal centres were most affected. This supports the view of Appelrath (1943), that the cartilage is more susceptible to frostbite than the bone. The distal ends of the distal phalanges were normal. In the case described by Bennett and Blount (1935) and the one presented by Thelander (1950), only one hand was affected and the middle and distal interphalangeal joints were destroyed. In the case reported by Löhr (1930), the third, fourth and fifth fingers in the distal interphalangeal 


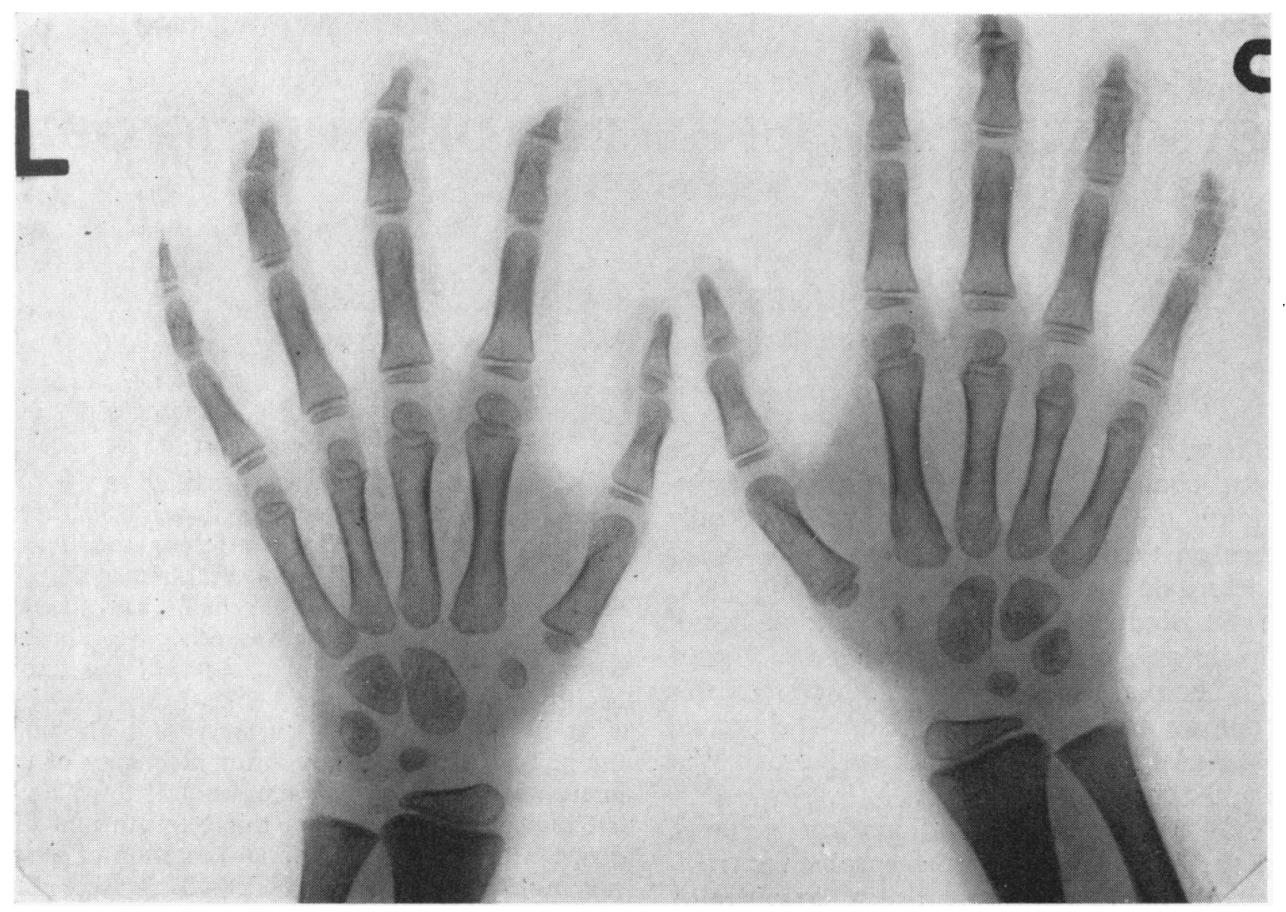

FIG. 1. Radiograph of the boy's hands.

joints, and the fourth and fifth fingers in the middle interphalangeal joints were changed symmetrically. This case is very similar to ours, in which the distal interphalangeal joints of both hands were affected, being more marked on the right side. This is worth stressing, as it may simulate systematic disturbances of epiphyseal growth from other causes (Thiemann, 1909-10; Fleischner, 1923; Steingräber, 1950; Liess, 1954; Staples, 1943). Caffey (1961) claims that some cases described as Thiemann's disease may be the result of frostbite. Such was the diagnosis for our patient, until we studied the radiographs.

\section{Summary}

A case of symmetrical bone changes after frostbite in a 5-year-old boy is described. The importance of differentiation from other systemic disturbances of epiphyseal growth, especially Thiemann's disease, is stressed.
I wish to thank Dr. John Caffey for his advice.

\section{REFERENCES}

Appelrath, C. (1943). Knochenschädigungen durch Kälte und deren Beobachtung im Röntgenbilde. Röntgenpraxis, 15, 241.

Bennett, R. B. and Blount, W. P. (1935). Destruction of epiphyses by freezing. J. Amer. med. Ass., 105, 661.

Caffey, J. (1961). Pediatric X-ray Diagnosis, 4th ed., p. 982. Year Book Medical Publishers, Chicago.

Fleischner, -. (1923). Multiple Epiphysenstörungen an den Händen. Fortschr. Röntgenstr., 31, 206.

Jäger, - ., cited by Appelrath, C. (1943). Knochenschädigungen durch Kälte und deren Beobachtung im Röntgenbilde. Röntgen-

praxis, 15, 241.
Liess, G. (1954). Die Nebenkernbildung bei der normalen und gestörten Epiphysenossifikation, und ihre Beziehung zu den aseptischen Nekrosen. Fortschr. Röntgenstr., 80, 153.

Löhr, W. (1930). Die Verschiedenheit der Auswirkung gleichartiger bekannter Schäden auf den Knochen Jugendlicher und Erwachsener, gezeigt an Epiphysenstörungen nach Erfrierungen und bei der Hämophilie. Zbl. Chir., 57, 898.

Staples, O. S. (1943). Osteochondritis of the epiphysis of the terminal phalanx of a finger. J. Bone Jt Surg., 25, 917.

Steingräber, M. (1950). Das Röntgenbild aseptischer Nekrosen an den Fingergelenken. Fortschr. Röntgenstr., 73, 220.

Thelander, H. E. (1950). Epiphyseal destruction by frostbite. J. Pediat., 36, 105.

Thiemann, H.' (1909-10). Juvenile Epiphysenstörungen. Fortschr. Röntgenstr., 14, 79.

Vinson, H. A. and Schatzki, R. (1954). Roentgenologic bone changes encountered in frostbite, Korea, 1950-1951. Radiology, 63,685 . 